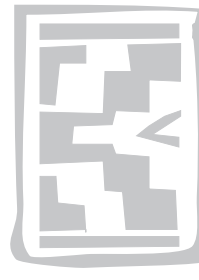

\title{
Cryptosporidium infection in non-human hosts in Malawi
}

Z. BANDA ${ }^{1}$, ROSELY A.B. NICHOLS ${ }^{2}$, A.M. GRIMASON ${ }^{2,3}$ and H.V. SMITH ${ }^{2}$

\begin{abstract}
BANDA, Z., NICHOLS, ROSELY A.B., GRIMASON, A.M. \& SMITH, H.V. 2009. Cryptosporidium infection in non-human hosts in Malawi. Onderstepoort Journal of Veterinary Research, 76:363-375

Of 1346 faecal samples from the Chikwawa and Thyolo districts of Malawi, analysed for the presence of Cryptosporidium oocysts between October 2001 and May 2003, 61.3\% were from cattle $(29.8 \%$ of these were from calves $<6$ months old). Cryptosporidium oocysts were detected during all three seasons studied in Chikwawa and Thyolo. In Chikwawa, $13.6 \%$ of adult cattle and $11.7 \%$ of calves were infected, compared to $28.9 \%$ of adult cattle and $36.7 \%$ of calves in Thyolo. Dependent on season, between $7.8 \%$ and $37.7 \%$ (Chikwawa) and $16.7 \%$ and $39.3 \%$ (Thyolo) of cattle samples contained oocysts. In Chikwawa, the highest percentage of infections occurred in the cool season, whereas in Thyolo, the highest percentage of infections occurred in the dry season. Faecal samples from goats [ $n=225]$, pigs [ $n=92]$, sheep [ $n=6]$ ), rabbits, guinea pigs, chickens, ducks, turkeys, doves and guinea fowls were also analysed. Up to $5.6 \%$ of goat samples contained oocysts in Chikwawa, compared to between $16.7 \%$ and $39.3 \%$ in Thyolo. Again, in Chikwawa, the highest percentage of infections occurred in the cool season and the lowest in the rainy season, whereas, in Thyolo, the highest percentage of infections occurred in the dry season and the lowest in the cool season. In pigs, more infections were detected in the dry season in Chikwawa, but infections in the cool season were similar (17.7\%), whereas in Thyolo, infections occurred in all three seasons (17.9\% in the rainy season, $25 \%$ in the cool season and $60 \%$ in the dry season). Of ten diarrhoeic, oocyst positive cattle faecal samples collected from Chikwawa and subjected to PCR-RFLP, four oocyst positive samples (two from heifers, one from a cow and one unknown) were amplified at an 18S rRNA and Cryptosporidium oocyst wall protein (COWP) loci. RFLP of the 18S rRNA locus indicated that Cryptosporidium parvum, Cryptosporidium hominis, Cryptosporidium bovis and / or Cryptosporidium ryanae DNA, or a mixture of them was present. Cryptosporidium parvum DNA was identified in one sample that amplified at the COWP locus, indicating the presence of the major zoonotic Cryptosporidium species in Malawi.
\end{abstract}

Keywords: Cattle, Cryptosporidium parvum, livestock, Malawi, oocysts, season

\section{INTRODUCTION}

The apicomplexan parasite, Cryptosporidium, is responsible for many outbreaks of human disease

* Author to whom correspondence is to be directed: E-mail: huw.smith@ggc.scot.nhs.uk

1 Department of Environmental Health, University of Malawi, Polytechnic, Private Bag 303, Chichiri, Blantyre 3, Malawi

2 Scottish Parasite Diagnostic Laboratory, Stobhill Hospital, Glasgow G21 3UW, Scotland, United Kingdom

3 Environmental Health, Department of Civil Engineering, Glasgow G4 ONG, Scotland, United Kingdom

Accepted for publication 6 April 2009-Editor affecting both immunocompetent and immunocompromised individuals (Cacciò, Thompson, McLauchlin \& Smith 2005). Cryptosporidiosis is also of veterinary importance since farm animals can be infected with various Cryptosporidium species that cause morbidity, with subsequent economic consequences (Smith 2008). Cryptosporidium has a large range of host species and infected hosts can shed large numbers of viable, environmentally robust oocysts that contaminate wastewater, watersheds, surface and ground waters and foods (Fayer 2008; Smith, Cacciò, Cook, Nichols \& Tait 2007). In humans inhabiting many regions of the world, Cryptosporidium 
constitutes part of the complex group of parasitic, bacterial and viral diseases that impair the ability to achieve full potential and impair development and socio-economic improvements. All diseases included in the World Health Organisation (WHO) Neglected Diseases Initiative have a common link with poverty and, as the current view is to take a comprehensive approach to all these diseases, Cryptosporidium was included in the 'Neglected Diseases Initiative' in 2005 (Savioli, Smith \& Thompson 2006).

The epidemiology of Cryptosporidium is complex with many hosts harbouring more than one species that can cross host species barriers, and having at least one host-adapted species, which are less likely to cross host barriers (Fayer 2008; Smith 2008). Of the 21 recognised Cryptosporidium species, humans can be infected with Cryptosporidium parvum, Cryptosporidium hominis, Cryptosporidium meleagridis, Cryptosporidium felis, Cryptosporidium muris, Cryptosporidium canis, Cryptosporidium suis and the Cryptosporidium cervine, monkey, skunk and rabbit genotypes (Caccio et al. 2005; Nichols, Chalmers, Sopwith, Regan, Hunter, Grenfell, Harrison \& Lane 2006), but two species, C. parvum and C. hominis, cause the majority of human disease (Caccio et al. 2005). In livestock, C. parvum, Cryptosporidium andersoni, Cryptosporidium baileyi and C. meleagridis cause disease (Smith 2008). Cryptosporidium parvum cryptosporidiosis is a cause of scours in young, unweaned livestock, and is the species recognized for having the greatest zoonotic potential.

Transmission of Cryptosporidium occurs following the ingestion of the environmentally robust transmissive stage, the oocyst. Transmission can be direct or indirect. Direct routes include person to person, animal to animal, and animal to person (zoonotic) and indirect routes include contaminated faeces and soil, surface and ground water, wastewater, feed, herbage, vectors and equipment (Cacciò et al. 2005; Smith, Cacciò, Tait, McLauchlin \& Thompson 2006; Smith et al. 2007; Xiao \& Feng 2008).

High mortality due to cryptosporidiosis has been reported in cattle mainly among meat breeds (Sanford \& Josephson 1982; Peeters, Villacorta, Vanopdenbosch, Vandergheynst, Naciri, Ares-Mazas \& Yvore 1992). Cryptosporidium andersoni infection in cattle is known to affect weight gain (Anderson 1987) and milk production (Esteban \& Anderson 1995). Cryptosporidiosis in neonatal small ruminants such as goats and sheep can result in weight loss and retarded growth during the first few weeks of their life (Naciri, Yvore \& Leieux 1984) and mortality has been reported in goat kids (Vieira, Silva, Tolentino, Lima
\& Silva 1997) and adult goats (Johnson, Muirhead, Windsor, King, Al-Busaidy \& Cornelius 1999).

Oocyst occurrence surveys identify the cosmopolitan nature of the parasite, occurring in numerous developed and developing countries (Fayer 2008; Smith \& Grimason 2003; Gold \& Smith 2002). In east Africa, studies performed in Kenya (e.g. Estambale, Bwibo, Kang'ethe \& Chitayi 1989; Mwachari, Batchelor, Paul, Waiyaki \& Gilks 2003; Simwa, Chunge, Kinoti, Karumba, Wamola \& Kabiru 1989; Joyce, McGuigan, Elmore-Meegan \& Conroy 1996; Peng, Matos, Gatei, Das, Stantian-Pavlinic, Bern, Sulaiman, Glaberman, Lal \& Xiao 2001; Gatei, Greensill, Ashford, Cuevas, Parry, Cunliffe, Beeching \& Hart 2003; Gatei, Wamae, Mbae, Waruru, Mulinge, Tabitha, Gatika, Kamwati, Revathi \& Hart 2006), Uganda (Tumwine, Kekitiinwa, Bakeera-Kitaka, Ndeezi, Downing, Feng, Akiyoshi \& Tzipori 2005) and Malawi (Morse, Nichols, Grimason, Campbell, Tembo \& Smith 2007) have revealed infections in paediatric and adult immunocompetent and immunocompromised persons, but there are fewer studies investigating Cryptosporidium occurrence in non-human hosts (e.g. Mtambo, Sebatwale, Kambaraje, Muhairwa, Maeda, Kusiluka \& Kazwala 1997; Nizeyi, Mwebe, Nanteza, Cranfield, Kalema \& Graczyk 1999; Graczyk, DaSilva, Cranfield, Nizeyi, Kalema \& Pieniazek 2001). In the Chikwawa district of Malawi, an occurrence study in under-5-year-old children $(n=$ 848 ) revealed that $5.9 \%$ of children had cryptosporidiosis, $10(1.2 \%)$ of whom were infected with C. parvum (Morse et al. 2007).

At present, there is no information available regarding the prevalence of Cryptosporidium spp. in nonhuman hosts in Malawi. Owing to the importance of this parasite, and the potential for zoonotic transmission, a study was carried out in the Chikwawa and Thyolo Districts of Malawi with the main objective of determining the prevalence of Cryptosporidium spp. infection, primarily in cattle.

\section{MATERIALS AND METHODS}

\section{Study areas}

The study was carried out in Chikwawa and Thyolo Districts of the southern region of Malawi from October 2001 to May 2003. Chikwawa is $\sim 50 \mathrm{~km}$ from the commercial capital of Malawi, Blantyre, at an altitude of $\sim 200 \mathrm{~m}$ above sea level. It has mean annual maximum temperatures between $30-32^{\circ} \mathrm{C}$ and mean annual minimum temperatures between 18$20^{\circ} \mathrm{C}$, and has an annual rainfall of $\sim 800-1200 \mathrm{~mm}$. 
Thyolo is $\sim 39 \mathrm{~km}$ from Blantyre at an altitude of $\sim 820 \mathrm{~m}$ above sea level. It has mean annual maximum temperatures of $\sim 29^{\circ} \mathrm{C}$ and mean annual minimum temperatures of $\sim 19^{\circ} \mathrm{C}$ and has an annual rainfall of $\sim 1258 \mathrm{~mm}$.

\section{Study seasons and selection of village households}

The Chikwawa study was carried out during the dry, rainy and cool seasons from October 2001 to October 2002. Nine villages were sampled during the dry season (October 2001), rainy season between (October 2001 and August 2002 to October 2002) and the cool season (May 2002 to July 2002). The Thyolo study was also carried out during the dry, rainy and cool seasons. Twenty villages were sampled during the dry season (October 2002), rainy season between (August 2002 to October 2002) and the cool season (May 2003 to July 2003).

Permission was sought from relevant authorities to carry out the intended study in Chikwawa and Thyolo Districts. A series of meetings was held with chiefs, the Project Officer, Development Officers, Field Assistants and villagers to explain to them about the intended study in different areas of both Districts. From a list of volunteer village households who owned livestock and wished to participate in the study, 31 livestock owners volunteered to participate in Chikwawa and 34 livestock farmers in Thyolo.

\section{Sample collection}

Faecal samples were collected once per season from non-diarrhoeic and diarrhoeic young and adult animals into $50 \mathrm{~g}$ capped plastic sample containers (Enterprise Containers, Blantyre, Malawi). Farmers were visited between 05:00 and 09:00 before they released the animals from their kraals for foraging, browsing or grazing. The animals were stimulated to defaecate by making them move about in their kraals. A faecal sample was scooped using a clean wooden applicator stick from the centre of the stool and carefully placed into a clean plastic container which was sealed and identified with an unique sample number. The date of collection, village, sex, age, colour and condition of the animal, macroscopic appearance of the stool (diarrhoeic or formed), and name of the owner of the animal and of the sample collector were entered onto a form. Samples were transported in cool boxes to the laboratory at the University of Malawi, The Polytechnic (UMP), and stored at $4{ }^{\circ} \mathrm{C}$ until analysed.

\section{Cryptosporidium oocyst detection}

A representative portion of faeces (approx. $500 \mathrm{mg}$ ) was smeared onto a clean glass slide with a wooden applicator stick, air dried, fixed in methanol for 3 min and subjected to modified Ziehl Neelsen (mZN) staining (Casemore 1991; Smith 1992).

\section{Oocyst abundance}

Oocyst abundance was determined by assessing the average number of oocysts seen per ten fields $(1+=<5$ oocysts per field; $2+=>5$ oocysts per field; $3+=>20$ oocysts per field). Oocysts were identified using the 40x objective and confirmed under the 100x oil objective.

\section{Confirmation of putative Cryptosporidium oocysts}

A series of confirmatory procedures were performed at the Scottish Parasite Diagnostic Laboratory (SPDL) on UMP mZN putative Cryptosporidium oocyst positive samples obtained from Chikwawa in the rainy season (November 2001 to February 2002). Modified Ziehl Neelsen putative positives were reexamined using auramine phenol (AP) according to Casemore (1991) and Smith (1992) following formolether concentration (Allen \& Ridley 1970). AP and mZN positive samples were also re-examined using a fluorescein isothiocyanate monoclonal antibody (FITC-C-mAb) (Crypt-a-glo, Waterborne Inc., New Orleans, USA) and the nuclear intercalator 4' 6 diamidino-2-phenyl indole (DAPI) (Grimason, Smith, Parker, Bukhari, Campbell \& Robertson 1994; Smith, Campbell, Paton \& Nichols 2002). Ten mZN, AP and FITC-C-mAb positive samples were then analysed by polymerase chain reaction and restriction fragment length polymorphism (PCR-RFLP) at both an 18S rRNA locus (N-18S rRNA( (Nichols, Campbell \& Smith 2003) and the single tube nested Cryptosporidium oocyst wall protein (STN-COWP) locus (Homan, Van Gorkom, Kan \& Hepener 1999).

\section{Epifluorescence microscopy}

Oocysts were visualized by epifluorescence microscopy and their internal morphology assessed using Nomarski differential interference contrast (DIC) microscopy. A blue filter block (excitation $490 \mathrm{~nm}$; emission $510 \mathrm{~nm}$ ) was used to visualize FITC-CmAb localization and an ultra-violet (UV) excitation (excitation $355 \mathrm{~nm}$, emission $450 \mathrm{~nm}$ ) was employed to determine the presence of DAPI-stained sporozoite nuclei. All assessments of the presence of fluorescent nuclei and internal morphology were undertaken at either $400 x$ or $1000 x$ magnification. 


\section{Molecular typing}

\section{Oocyst purification and DNA extraction}

Cryptosporidium oocyst positive samples were purified by water ether concentration (Bukhari \& Smith 1995; Nichols, Moore \& Smith 2006) or immunomagnetic separation (IMS, Dynal A.S. Oslo, Norway) according to the manufacturer's instructions. Oocysts were suspended in lysis buffer $[50 \mathrm{mM}$ Tris- $\mathrm{HCl} \mathrm{pH}$ 8.5, $1 \mathrm{mM}$ EDTA, $0.5 \%$ sodium dodecyl sulphate (SDS)] and DNA was released from oocysts following 15 cycles of freeze-thawing (freezing in liquid nitrogen for $1 \mathrm{~min}$, followed by thawing at $65^{\circ} \mathrm{C}$ for $1 \mathrm{~min}$ ). Proteinase $\mathrm{K}$ (final concentration $200 \mu \mathrm{g}$ $\mathrm{ml}^{-1}$ ) was added, and the samples incubated at $55^{\circ} \mathrm{C}$ in a water bath, for $3 \mathrm{~h}$. Proteinase $\mathrm{K}$ was heat denatured $\left(90^{\circ} \mathrm{C}, 20 \mathrm{~min}\right)$, samples chilled on ice for $1 \mathrm{~min}$, and centrifuged for $5 \mathrm{~min}$ at $10000 \times \mathrm{g}$ (Nichols \& Smith 2004). The supernatant $(70 \mu \ell)$ was transferred to a clean tube and either used immediately for PCR amplification or stored at $-20^{\circ} \mathrm{C}$ until used.

\section{PCR protocol}

PCR amplifications were performed in Perkin Elmer thermocycler model 480 in $0.5 \mathrm{ml}$ thin-walled tubes. For the direct $18 \mathrm{~S}$ rRNA PCR reaction volumes of $100 \mu \ell$ consisted of pre-mixed reagents consisting of $200 \mu \mathrm{M}$ of each of the four dNTP's (Amersham Pharmacia Biotech UK Ltd., Amersham Place, Little Chalfont, Bucks., HP7 9NA, UK), $0.2 \mu \mathrm{M}$ each of primers CPBDIAGF/R (Cruachem, Todd Campus Acre Road, Glasgow, G20 0UA, UK), bovine serum albumin at final concentration of $400 \mu \mathrm{g} \mathrm{m}^{-1}, \mathrm{MgCl}_{2}$ at $3.5 \mathrm{mM}, 2.5 \mathrm{U}$ of Taq polymerase (Advanced Biotechnologies, Holly Ditch Farm, Mile Elm, Calne, Wiltshire, SN11 OPY, UK) in 1 x PCR buffer IV (Advanced Biotechnologies) and Tween 20 at a final concentration of $2 \%$ to inactivate $0.05 \%$ sodium dodecyl sulphate. Approximately $40 \mu \ell$ of mineral oil was layered on top of each tube containing the dispensed PCR mix and $10 \mu \ell$ of DNA template was pipetted under the oil. Positive controls consisted of C. parvum oocyst DNA and negative controls were DNA-free reaction tubes. Samples were subjected to 39 cycles of amplification according to Johnson, Pieniazek, Griffin, Misener \& Rose 1995) and the $435 \mathrm{bp}$ PCR product was visualized following ethidium bromide staining of $1.4 \%$ agarose gels (Nichols et al. 2003, 2006). PCR protocol for the STN-COWP locus was according to Homan et al. (1999) with the inclusion of bovine serum albumin and Tween 20 in the PCR mixture as described above.
Cryptosporidium species identification by PCR-RFLP analysis

Twenty $\mu$ of $18 S$ rRNA PCR product were simultaneously digested with $20 \mathrm{U}$ of each restriction enzymes Ase I (New England Biolabs, 75-77 Knowl Piece, Wilbury Way, Hitchin, Herts, SG4 OTY, UK and Dral (Invitrogen, 3 Fountain Drive, Inchinnan Business Park, Renfrew, PA4 9RF, UK) in $50 \mu \mathrm{l}$ of $1 \times$ NE Buffer 3 (New England Biolabs) for $2 \mathrm{~h}$ at $37^{\circ} \mathrm{C}$. Ten microliters of PCR product from the STNCOWP assay (Homan et al. 1999) was digested with $10 \mathrm{U}$ of restriction enzyme Taq I (Invitrogen) according to the supplier's instructions. Undigested controls were run alongside the digested fragments in a $2 \%$ agarose gel at 100 volts for $1-2 \mathrm{~h}$ and stained with ethidium bromide $\left(0.5 \mu \mathrm{g} \mathrm{m \ell ^{-1 }}\right)$ incorporated in the gel and the running buffer.

\section{Quality assurance}

All diagnostic methods performed at SPDL were conducted in compliance with the Standard Operating Procedures accredited by Clinical Pathology Accreditation (UK) Ltd. and the Drinking Water Inspectorate (Regulatory Cryptosporidium Standard Operating Procedures). All methods performed at UMP are accredited at SPDL.

\section{RESULTS}

\section{Cryptosporidium in Malawian faecal samples}

A total of 1346 faecal samples were analysed. Of these, 905 were from Chikwawa consisting of 559 samples collected in the dry season, 189 in the rainy season and 157 in the cool season, and 441 samples were from Thyolo consisting of 219 samples collected in the dry season, 114 in the rainy season and 108 in the cool season. Cryptosporidium oocysts were present in $16.7 \%(224 / 1346)$ of samples, with a similar rate of occurrence in Chikwawa $(7.7 \%$, 104/1 346) and in Thyolo (8.9 \%, 120/1 346).

The number of animal species sampled and the percentage positivity in the three seasons from both Chikwawa and Thyolo are presented in Table 1. The percentage of samples that was oocyst positive was dependent on season in the two districts sampled, with the highest percentage positives detected in the cool season (31.9\%) in Chikwawa and in the dry season (34.7\%) in Thyolo (Table 2).

The majority of samples were from cattle $(61.3 \%$, $825 / 1346$ ), with $47.6 \%$ being from cows, $14.2 \%$ from heifers, $7 \%$ from bulls, $1.4 \%$ from oxen (cas- 

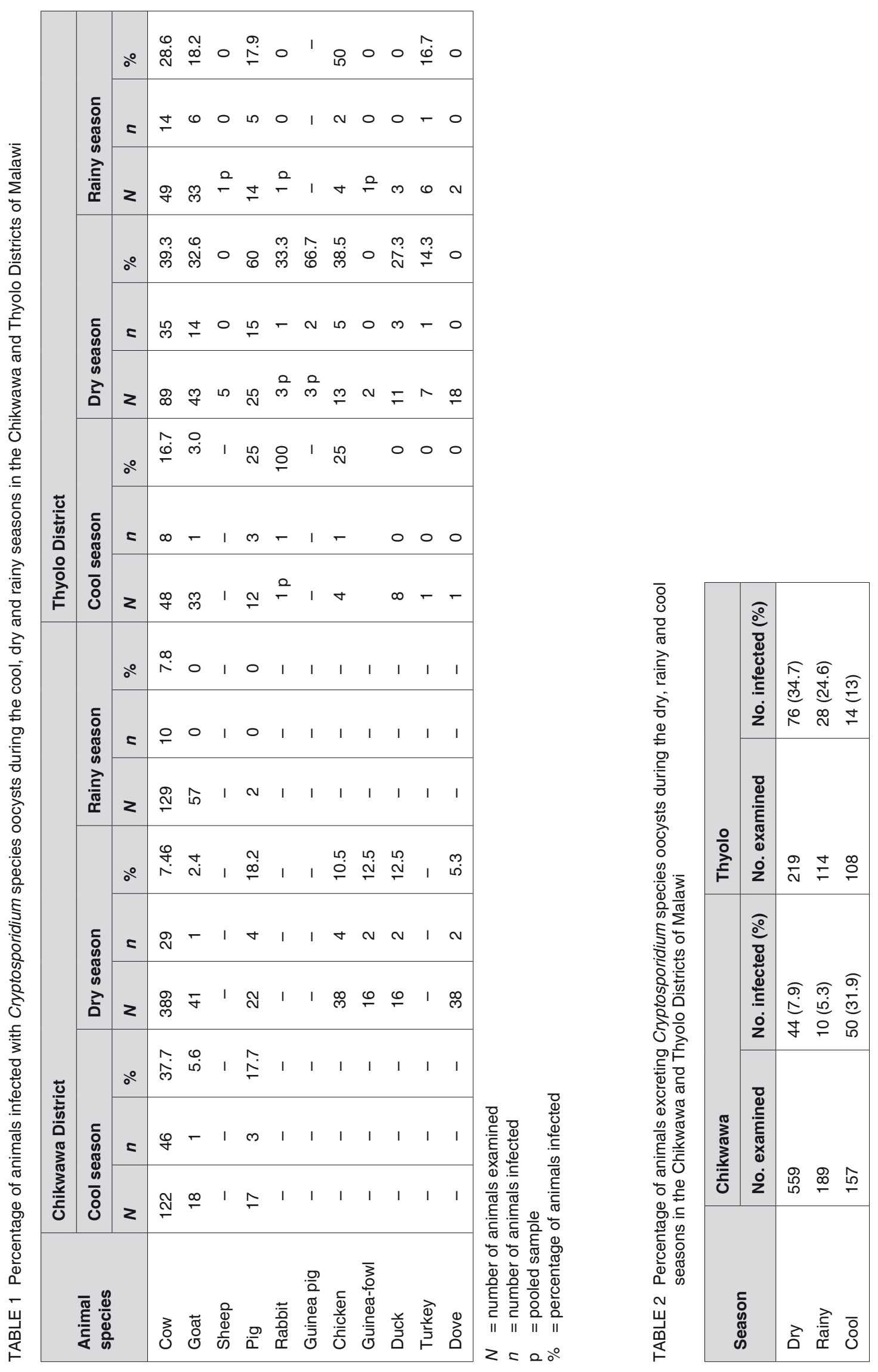

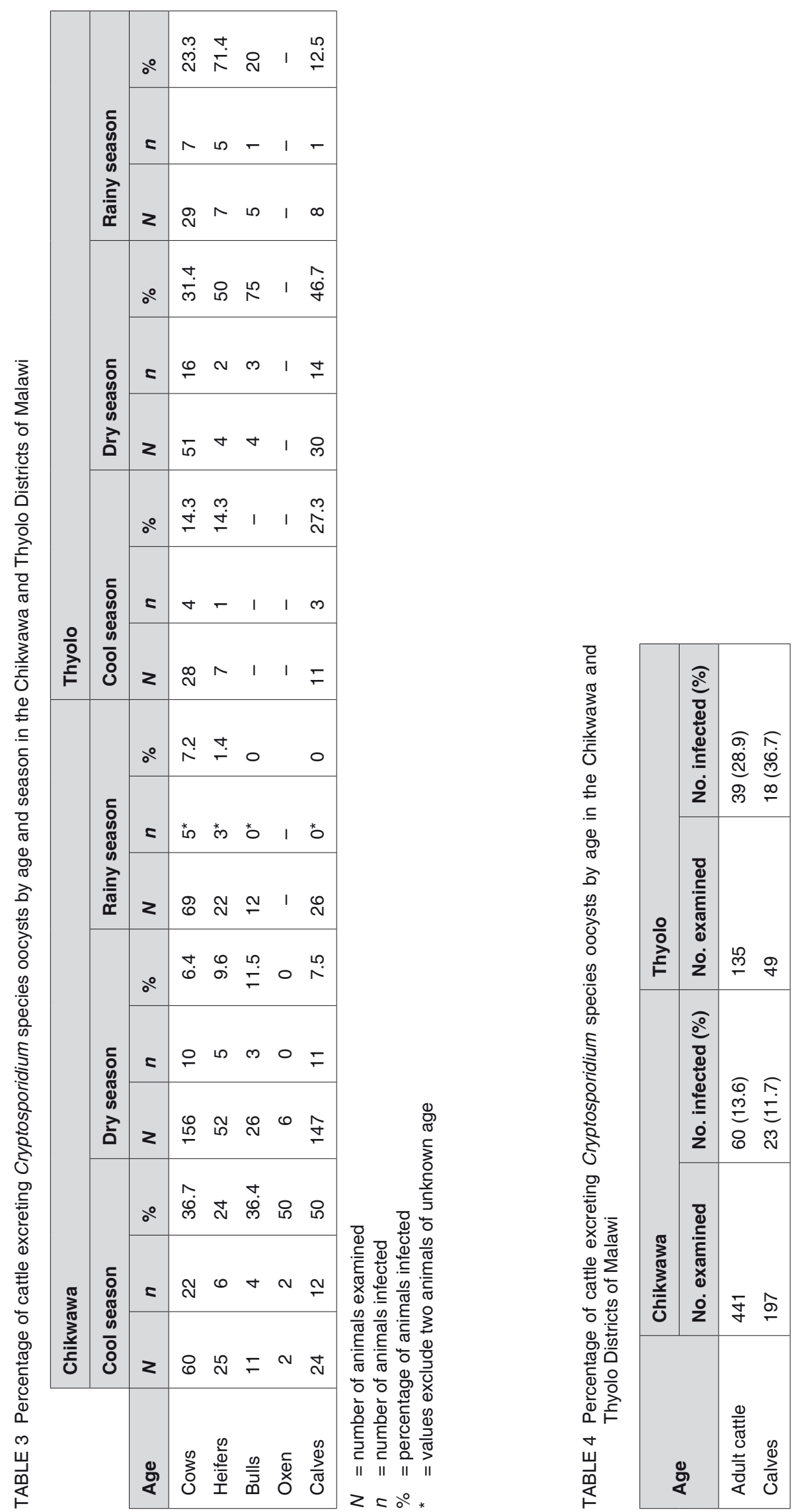


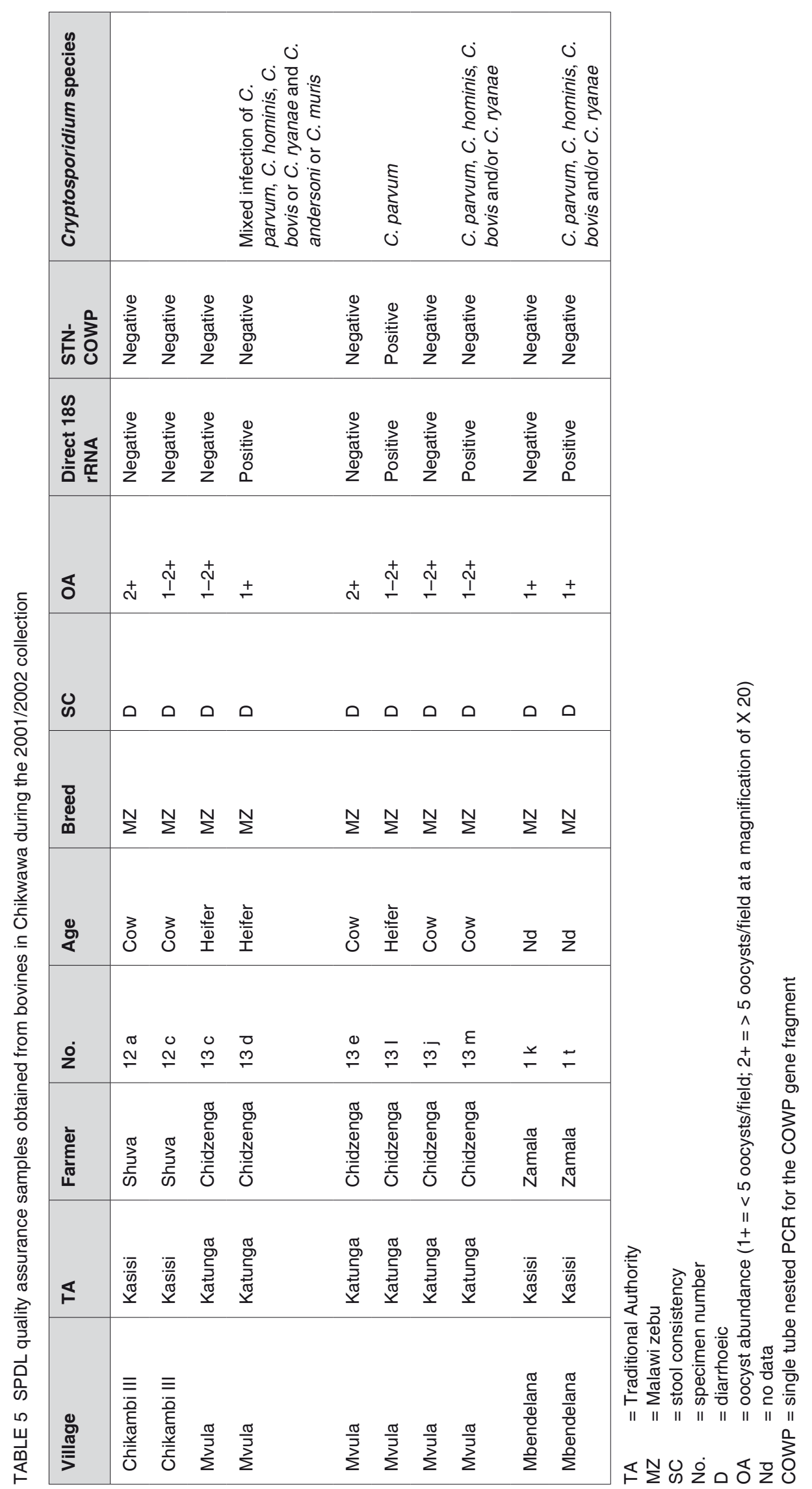


trated males) and $29.8 \%$ from calves ( $<6$ months old). Stool samples from other mammalian livestock (goats [ $n=225]$, pigs [ $n=92]$ and sheep [ $n=6]$ ), as well as rabbits, guinea pigs, chicken, ducks, turkeys, doves and guinea fowls) were also analysed ( $n=$ 197; Table 1).

In Chikwawa, between $7.8 \%$ and $37.7 \%$ of cattle samples contained oocysts, dependent on season, with the highest percentage of infections occurring in the cool season and the lowest in the rainy season (Table 1). In Thyolo, between $3 \%$ and $32.6 \%$ of cattle samples contained oocysts, dependent on season, with the highest percentage of infections occurring in the dry season and the lowest in the cool season (Table 1). In Chikwawa, between $0 \%$ and $5.6 \%$ of goat samples contained oocysts, with the highest percentage of infections again occurring in the cool season and the lowest in the rainy season (Table 1). In Thyolo, between $3 \%$ and $32.6 \%$ of goat samples contained oocysts, with the highest percentage of infections occurring in the dry season and the lowest in the cool season (Table 1). In Chikwawa, the highest percentage of infections in pigs were detected in the dry season, but infections in the cool season were similar (17.7\%), whereas in Thyolo, infections occurred in all three seasons $(17.9 \%$ in the rainy season, $25 \%$ in the cool season and $60 \%$ in the dry season) (Table 1).

Cryptosporidium infections in rabbits, guinea pigs, chicken, ducks, turkeys, doves and guinea fowls were also detected, and while the data indicate that infections were detected in these hosts, the data are sparse and do not cover all seasons analysed. Based on mZN positivity, Table 2 identifies the numbers and percentages of stools containing oocysts in our samples, over the three seasons analysed and serves as an indicator of the prevalence of Cryptosporidium in the Chikwawa and Thyolo Districts of Malawi. Cryptosporidium oocysts were more likely to be detected in the cool season in Chikwawa and in the dry season in Thyolo whereas oocysts were least likely to be detected in the dry season in Chikwawa and in the cool season in Thyolo. The agebased breakdown of Cryptosporidium oocyst positive samples from cattle is presented in Tables 3 and 4 . We detected Cryptosporidium oocysts during all three seasons in the Chikwawa and Thyolo districts of Malawi. In Chikwawa, $13.6 \%$ of adult cattle and $11.7 \%$ of calves were infected, compared to $28.9 \%$ of adult cattle and $36.7 \%$ of calves in Thyolo (Table 4). Season influenced Cryptosporidium occurrence in adult cattle and calves in Chikwawa and Thyolo. The highest percentages of oocyst positivity occurred in both older cattle and calves in the cool season in Chikwawa and in the dry season in Thyolo with nearly $50 \%$ of calves being infected (Table 3 ).

\section{Quality assurance at SPDL on UMP mZN putative Cryptosporidium oocyst positive samples obtained from cattle in Chikwawa}

Ten diarrhoeic faecal samples collected from Chikwawa (November 2001 to February 2002) which were $\mathrm{mZN}$ positive at UMP were also AP and IFAT positive at SPDL, indicating that the SPDL $\mathrm{mZN}$ Standard Operating Procedure used at UMP could detect Cryptosporidium spp. oocysts. These ten diarrhoeic samples were subjected to PCR-RFLP. Three (30\%) had an oocyst abundance of 1+, five (50\%) had an oocyst abundance of 1-2+ and two $(20 \%)$ had an oocyst abundance of $2+$ (Table 5). Four oocyst positive samples (two from heifers, one from a cow and 1 unknown) were amplified using the N-18SrRNA and STN-COWP assays. At the 18S rRNA locus, following Ase I /Dral digestion, all four samples showed a RFLP pattern that corresponds to $C$. parvum, C. hominis, C. bovis or C. ryanae (previously, Cryptosporidium deer-like genotype), or a mixture of them. Only one of the four 18S rRNA positive samples amplified at the STN-COWP locus and the RFLP pattern indicated the presence of $C$. parvum DNA.

\section{DISCUSSION}

This is the first study to report Cryptosporidium infection in Malawian livestock and other non-human hosts and is of potential veterinary and public health importance. It included most of the animals that the volunteer livestock owners possessed, and, as such, should also offer useful Cryptosporidium point prevalence data for livestock (primarily cattle) in the Chikwawa and Thyolo Districts of Malawi. Elsewhere, Cryptosporidium spp. have been shown to be a significant cause of morbidity in animals and humans, particularly among neonates and immunocompromised hosts. We detected Cryptosporidium oocysts in $16.7 \%$ of samples, with a similar rate of occurrence in both Chikwawa and Thyolo $(7.7 \%$ and $8.9 \%)$, respectively. With the exception of the ten quality assurance samples analysed at SPDL, all positive samples were detected using $\mathrm{mZN}$ at UMP. As all ten UMP mZN positive, quality assurance samples were also oocyst positive by AP and IFAT, we can be assured that the SPDL mZN Standard Operating Procedure used at UMP detects Cryptosporidium spp. oocysts. 
The absence of detectable oocysts in our unconcentrated samples (October 2001[dry season], November 2001 to February 2003 [rainy season]) does not signify that the animals tested did not harbour Cryptosporidium infection as our detection methods are insensitive. Using unconcentrated faecal smears, Anusz, Mason, Riggs \& Perryman (1990) reported a detection limit of $10^{6}$ oocysts $\mathrm{ml}^{-1}$ of faeces using Kinyoun staining. Oocyst concentration methods can increase the sensitivity of detection. Between $1 \mathrm{x}$ $10^{4}$ and $5 \times 10^{4}$ oocysts $g^{-1}$ of unconcentrated stool are necessary to obtain a $100 \%$ detection efficiency using the Kinyoun staining method (Weber, Bryan, Bishop, Wahlquist, Sullivan \& Juranek 1991). Variations in faecal consistency influence the ease of detection, with oocysts being more easily detected in concentrates made from watery, diarrhoeal specimens than from formed stool specimens (Weber et al. 1991). Webster, Smith, Giles, Dawson \& Robertson (1996) reported that oocysts were not detected in bovine faecal samples seeded with $10^{4} \mathrm{C}$. parvum oocysts $\mathrm{g}^{-1}$ following formol ether concentration and examined using AP or IFAT, and that sucrose or salt flotation was required to increase the threshold of detection to $4-6 \times 10^{3}$ oocysts $\mathrm{g}^{-1}$ using AP or IFAT.

With the exception of the small numbers of sheep samples analysed $(n=6)$, Cryptosporidium spp. oocysts were detected in all other host species (Table 1), indicating the commonness of this parasite in Malawi. However, conventional staining methods (e.g. mZN, AP, IFAT) cannot determine the species/ genotype of Cryptosporidium infecting these hosts. The majority of samples analysed were from cattle $(61.3 \%)$, with $29.8 \%$ sampled from calves $(<6$ months old). Calves have been implicated in the zoonotic transmission of cryptosporidiosis, frequently (Mallon, MacLeod, Wastling, Smith, Reilly \& Tait 2003a; Mallon, MacLeod, Wastling, Smith, \& Tait 2003b; Geurden, Berkvens, Martens, Casaert, Vercruysse \& Claerebout 2007; Xiao \& Feng 2008).

Cattle can be infected with $C$. parvum, $C$. bovis, $C$. ryanae (previously, Cryptosporidium deer-like genotype), C. andersoni and C. suis (Fayer 2008) and cryptosporidiosis, due to $C$. parvum or $C$. andersoni, is a cause of production loses in cattle (Esteban \& Anderson 1995; Smith 2008). Neonatal cattle and sheep act as reservoirs for the zoonotic transmission of C. parvum (Smith et al. 2007). Whereas calves $<6$ months old are most likely to harbour $C$. parvum, older cattle are more likely to harbour the host adapted $C$. bovis and $C$. ryanae (Feng, Ortega, $\mathrm{He}$, Das, Zhang, Fayer, Gatei, Cama \& Xiao 2007).
Of the other livestock investigated, goats are infected with C. parvum (Fayer 2008), the C. bovis-like genotype and a novel Cryptosporidium genotype (now $C$. xiaoi, Fayer \& Santin 2009) (Karanis, Plutzer, Halim, Igori, Nagasawa, Ongerth \& Liqing 2007), pigs with C. suis, Cryptosporidium pig genotype II and C. parvum (Fayer, 2008; Zintl, Neville, Maguire, Fanning, Mulcahy, Smith \& De Waal 2007) and sheep with C. parvum, Cryptosporidium cervine genotypes 1-3 and Cryptosporidium sheep novel genotypes (Fayer 2008), C. hominis, C. andersoni, marsupial genotype, pig II genotype, and a novel unidentified genotype (Ryan, Bath, Robertson, Read, Elliot, Mclnnes, Traub \& Besier 2005), a novel C. bovis-like genotype (now C. xiaoi, Fayer \& Santin 2009; $99.9 \%$ sequence similarity with $C$. bovis) (Santin, Trout \& Fayer 2007).

In addition to the likelihood of some of these Cryptosporidium species causing disease in their major hosts, a zoonotic potential also exists for those animals infected with human infectious species, particularly, but not exclusively, those infected with $C$. parvum.

We detected Cryptosporidium oocysts during all three seasons in the Chikwawa and Thyolo Districts of Malawi. In Chikwawa, $13.6 \%$ of adult cattle and $11.7 \%$ of calves were infected, compared to $28.9 \%$ of adult cattle and $36.7 \%$ of calves in Thyolo (Table 4). Season influenced Cryptosporidium occurrence in adult cattle and calves in Chikwawa and Thyolo. Chikwawa experiences higher temperatures and lower annual rainfall than Thyolo, and temperature influences oocyst survival.

Oocysts remain infectious for up to 3 months when stored in water at ambient $\left(20-30^{\circ} \mathrm{C}\right)$ temperatures (Fayer, Trout \& Jenkins 1998) but higher temperatures and increased solar radiation increase Cryptosporidium oocyst inactivation in the environment (Fujino, Matsui, Kobayashi, Haruki, Yoshino, Kajima \& Tsui 2002; King, Daminato, Fanok \& Monis 2008). King et al. (2008) found that solar UV can rapidly inactivate $C$. parvum in environmental waters, and determined that solar radiation was a critical process affecting oocyst survival in the environment. Animal management systems also differ in Chikwawa and Thyolo. In Chikwawa District most cattle are beef cattle and free range grazers, whereas, in Thyolo, the majority of cattle are dairy cattle and are housed and fed using the cut and carry method. Increased milk production demands and scarcity of feed can cause body condition loss and increased susceptibility to infectious diseases. These season- 
al, temperature and animal management regime differences warrant further investigation.

As age influences the species of Cryptosporidium infecting bovines, with calves less than 6 months old being most likely to harbour the zoonotic species, C. parvum (Feng et al. 2007), there should be a greater potential for the zoonotic spread of $C$. parvum in the cool season in Chikwawa and in the dry season in Thyolo, where infection in calves was highest ( $50 \%$; Table 3). Furthermore, the zoonotic potential might be greater in Thyolo than in Chikwawa, as $36.7 \%$ of calves were infected in the former compared with $11.7 \%$ in the latter district (Table 4).

Cryptosporidium is a common infection of bovines worldwide. Kaminjolo, Adesiyun, Loregnard \& Kitson-Piggot (1993) reported a prevalence of $8.7 \%$ in calves in Trinidad and Tobago, and, based on single samplings, Cryptosporidium prevalence rates in calves ranging from $5.6-79.0 \%$ have been reported from the USA (Sobieh, Tacal, Wilcke, Lawrence \& El-Ahraf 1987; Ongerth \& Stibbs 1989). Mtambo et al. (1997) stated that $5.3 \%$ of bovine faecal samples in Tanzanian farms contained oocysts and that Cryptosporidium prevalence was higher in calves $<3$ months of age compared to weaned calves and adults. Huetink, Giessen, Noordhuizen \& Ploeger (2001) reported Cryptosporidium prevalence to be $2.4-22.2 \%$ in a dairy cattle herd in The Netherlands. A Spanish study reported a $C$. parvum prevalence of $7.7 \%$ in fattening calves and heifers between 4-24 months old and $17.8 \%$ in adult cattle (Quilez, Sanchez-Acedo, del Cacho, Clavel \& Causape 1996). Cryptosporidium prevalences of $10.5 \%$ in dairy cows, $8.7 \%$ in heifers and $28.8 \%$ in beef cattle (Fayer, Trout, Graczyk \& Lewis 2000), $70.2 \%$ in asymptomatic adult cattle (Lorenzo-Lorenzo, AresMazas \& Villacorta-Martinez de Maturana 1993), $17.8 \%$ in asymptomatic cattle over 2 years of age (Quilez et al. 1996), 81\% in 2-36 day-old calves, $15 \%$ in $1.5-4.5$ month-old post-weaned calves, $0 \%$ in 20-24 month-old heifers (Ares-Mazas, Fernandez-da Ponte, Vergara-Castiblanco, Frieve-Santos, Quilez-Cinca, Causape-Valenzuela \& SanchezAcedo 1999), $62.4 \%$ in apparently health adult cattle (Scott, Smith, Mtambo \& Gibbs 1995) and $19 \%$ in adult dairy cows (Bukhari \& Smith 1996) have been documented. These findings are in agreement with the results of this study.

This study clearly demonstrates the presence of Cryptosporidium infections in a variety of avian and mammalian hosts in Malawi, indicating the potential role of such hosts as reservoirs of infectious parasites, and in particular infections in post-weaned and adult cattle. Although we did not use molecular typing tools in our survey, we did use them for quality assurance. Four of the ten mZN, AP and IFAT positive samples used for quality assurance at SPDL were amplified by PCR using the direct $18 \mathrm{~S}$ rRNA gene locus, but only one oocyst positive sample amplified at the STN-COWP locus. The direct 18S rRNA gene locus can determine all Cryptosporidium species after sequencing, while the STNCOWP locus can identify $C$. parvum, $C$. hominis and C. meleagridis by RFLP (Jiang \& Xiao 2003). Although each oocyst contains 20 copies of the $18 \mathrm{~S}$ rRNA gene, the direct 18S rRNA PCR was only marginally sensitive with these ten oocyst positive slides. The expansion of valid Cryptosporidium species in the last 5 years (Smith et al. 2007) identifies that RFLP analysis is becoming less useful currently, as Ase I and Dral digestion of the 18S rRNA amplicon cannot discriminate between C. parvum, $C$. hominis, C. bovis and C. ryanae. The C. parvum RFLP pattern was identified from the only oocyst positive sample that amplified at the STN-COWP single copy gene locus. The low PCR positivity rate using these loci may be due to co-extraction of inhibitors with DNA, the amount of DNA template extracted and/or the absence of nuclear material within the oocysts. Most of our microscopy positive samples had low oocyst abundances (highest oocyst abundance $=2+$ ), possibly indicating either the tailing off of cryptosporidiosis or asymptomatic infection and the low sensitivity of mZN. Cryptosporidium parvum was unambiguously detected in one $(10 \%)$ sample (heifer; Table 5) establishing that $C$. parvum infection occurs in Malawian cattle. Since C. parvum can infect susceptible human and nonhuman hosts, this species has both veterinary and public health significance in Malawi.

\section{ACKNOWLEDGEMENTS}

We thank the University of Malawi, University of Strathclyde Malawi Millenium Project and the British Council, Malawi for making this study possible.

\section{REFERENCES}

ALLEN, A.V.H. \& RIDLEY, D.S. 1970. Further observations in the formol-ether concentration technique for faecal parasites. Journal of Clinical Pathology, 27:545-546.

ANDERSON, B.C. 1987. Abomasal cryptosporidiosis in cattle. Veterinary Pathology, 24:235-238.

ANUSZ, K., MASON, P., RIGGS, M. \& PERRYMAN, L.1990. Detection of Cryptosporidium parvum oocysts in bovine faeces by monoclonal antibody capture enzyme-linked immuno- 
sorbent assay. Journal of Clinical Microbiology, 28:27702774.

ARES-MAZAS, M.E., FERNANDEZ-DA PONTE, B., VERGARACASTIBLANCO, C.A., FRIEVE-SANTOS, F., QUILEZCINCA, J., CAUSAPE-VALENZUELA, A.C. \& SANCHEZACEDO, C. 1999. Oocysts, IgG levels and immunoblot patterns determined for Cryptosporidium parvum in bovine examined during a visit to a farm (northeastern Spain). Veterinary Parasitology, 81:185-193.

BUKHARI, Z. \& SMITH, H.V. 1995. Effect of three concentration techniques on viability of Cryptosporidium parvum oocysts recovered from bovine feces. Journal of Clinical Microbiology, 33:2592-2595

BUKHARI, Z. \& SMITH, H. V. 1996. Detection of Cryptosporidium muris oocysts in faeces of adult dairy cattle in Scotland. Veterinary Record, 138:207-208.

CACCIÒ, S.M., THOMPSON, R.C.A., MCLAUCHLIN, J. \& SMITH, H.V. 2005. Unravelling Cryptosporidium and Giardia epidemiology. Trends in Parasitology, 21, 430-437.

CASEMORE, D. P. 1991. Laboratory methods for diagnosing cryptosporidiosis. ACP Broadsheet, 128:445-451.

ESTAMBALE, B,B,, BWIBO, C.R., KANG'ETHE, S. \& CHITAYI, P.M. 1989. The occurrence of Cryptosporidium oocysts in faecal samples submitted for routine examination at Kenyatta National Hospital. East African Medical Journal, 66:792-795.

ESTEBAN, E. \& ANDERSON, B.C. 1995. Cryptosporidium muris: prevalence, persistency and detrimental effect on milk production in a drylot dairy. Journal of Dairy Science, 78:10681072.

FAYER, R., TROUT, J.M. \& JENKINS, M.C. 1998. Infectivity of Cryptosporidium oocysts stored in water at environmental temperatures. Journal of Parasitology. 84:1165-1169.

FAYER, R., TROUT, J.M., GRACZYK, T. K. \& LEWIS, E.J. 2000. Prevalence of Cryptosporidium, Giardia and Eimeria infections in post-weaned and adult cattle on three Maryland farms. Veterinary Parasitology, 93:103-112.

FAYER, R. 2008. General biology of Cryptosporidium, in Cryptosporidiosis of man and animals, edited by R. Fayer \& L. Xiao. Boca Raton, FL, USA: CRC Press \& IWA Publishing.

FAYER, R. \& SANTIN, M. 2009. Cryptosporidium xiaoi n. sp. (Apicomplexa: Cryptosporidiidae) in sheep (Ovis aries). Veterinary Parasitology, 164:192-200.

FENG, Y., ORTEGA, Y., HE, G., DAS, P., ZHANG, X., FAYER, R., GATEI, W., CAMA, V. \& XIAO, L. 2007. Wide geographic distribution of Cryptosporidium bovis and the deer-like genotype in bovines. Veterinary Parasitology, 144:1-9.

FUJINO, T., MATSUI, T., KOBAYASHI, F., HARUKI, K., YOSHINO, Y., KAJIMA, J. \& TSUI, M. 2002. The effect of heating against Cryptosporidium oocysts. Journal of Veterinary Medical Science, 64:199-200.

GATEI, W., GREENSILL, J., ASHFORD, R.W., CUEVAS, L.E., PARRY, C.M., CUNLIFFE, N.A., BEECHING. N.J. \& HART, C.A. 2003. Molecular analysis of the 18S rRNA gene of Cryptosporidium parasites from patients with or without human immunodeficiency virus infections living in Kenya, Malawi, Brazil, the United Kingdom, and Vietnam. Journal of Clinical Microbiology, 41:1458-1462.

GATEI, W., WAMAE, C.N., MBAE,C. ,WARURU, A., MULINGE, E., TABITHA W., GATIKA, S.M., KAMWATI, S.K., REVATHI, G. \& HART, C.A. 2006. Cryptosporidiosis: prevalence, genotype analysis, and symptoms associated with infections in children in Kenya. American Journal of Tropical Medicine and Hygiene, 75:78-82.
GEURDEN, T., BERKVENS, D., MARTENS, C., CASAERT, S., VERCRUYSSE, J. \& CLAEREBOUT, E. 2007. Molecular epidemiology with subtype analysis of Cryptosporidium in calves in Belgium. Parasitology, 134:1981-1987.

GOLD, D. \& SMITH, H. 2002. Pathogenic protozoa in fresh and drinking water, in Detection methods for algae, protozoa and helminths in fresh and drinking water, edited by F. Palumbo, G. Ziglio \& A. van der Beken. Chichester, England: John Wiley \& Sons.

GRACZYK, T.K., DASILVA, A.J., CRANFIELD, M.R., NIZEYI, J.B., KALEMA, G.R. \& PIENIAZEK, N.J. 2001. Cryptosporidium parvum genotype 2 infections in free-ranging mountain gorillas (Gorilla gorilla beringeI) of the Bwindi Impenetrable National Park, Uganda. Parasitology Research, 87:368-370.

GRIMASON, A.M., SMITH, H.V., PARKER, J.F.W., BUKHARI, Z., CAMPBELL, A.T. \& ROBERTSON, L.J. 1994. Application of DAPI and immunofluorescence for enhanced identification of Cryptosporidium species oocysts in water samples. Water Research, 28:733-736.

HOMAN, W., VAN GORKOM, T., KAN, Y. Y. \& HEPENER. J. 1999. Characterization of Cryptosporidium parvum in human and animal feces by single-tube nested polymerase chain reaction and restriction analysis. Parasitology Research, 85: 707-712.

HUETINK, R.E.C., GIESSEN, J.W.B, NOORDHUIZEN, J.P.T.M. \& PLOEGER, H.W. 2001. Epidemiology of Cryptosporidium species and Giardia duodenalis on a dairy farm. Veterinary Parasitology, 102:53-67.

JIANG, J, \& XIAO, L. 2003. An evaluation of molecular diagnostic tools for the detection and differentiation of human-pathogenic Cryptosporidium spp. Journal of Eukaryotic Microbiology, 50:542-547 (Suppl).

JOHNSON, D.W., PIENIAZEK, N.J., GRIFFIN, D.W., MISENER, L. \& ROSE, J.B. 1995. Development of PCR protocol for sensitive detection of Cryptosporidium in water samples. Applied and Environmental Microbiology, 61:3849-3855.

JOHNSON, E.H., MUIRHEAD, D.E., WINDSOR, J.J., KING, G.J., AL-BUSAIDY, R. \& CORNELIUS, R. 1999. A typical outbreak of caprine cryptosporidiosis in Sultanate of Oman. Veterinary Record, 145:521-524.

JOYCE, T., McGUIGAN, K.G., ELMORE-MEEGAN, M. \& CONROY, R.M. 1996. Prevalence of enteropathogens in stools of rural Maasai children under five years of age in the Maasailand region of the Kenyan Rift Valley. East African Medical Journal, 73:59-62.

KAMINJOLO, J.S., ADESIYUN, A.A., LOREGNARD, R. \& KITSON-PIGGOT, W. 1993. Prevalence of Cryptosporidium oocysts in livestock in Trinidad and Tobago. Veterinary Parasitology, 45:209-213.

KARANIS, P., PLUTZER, J., HALIM, NA., IGORI, K., NAGASAWA, H., ONGERTH, J. \& LIQING, M. 2007. Molecular characterization of Cryptosporidium from animal sources in Qinghai province of China. Parasitology Research, 101:15751580.

KING, B.J., DAMINATO, D.P., FANOK, S. \& MONIS, P.T. 2008. Solar UV reduces Cryptosporidium parvum oocyst infectivity in environmental waters. Journal of Applied Microbiology, 104:1311-1323.

LORENZO-LORENZO, M.J., ARES-MAZAS, E. \& VILLACORTAMARTINEZ DE MATURANA, I. 1993. Detection of oocysts and IgG antibodies to Cryptosporidium parvum in asymptomatic adult cattle. Veterinary Parasitology, 47:9-15.

MALLON, M., MACLEOD, A., WASTLING, J., SMITH, H.V., REILLY, W.J. \& TAIT., A. 2003a. Population structures and the role of genetic exchange in the zoonotic pathogen Cryp- 
tosporidium parvum. Journal of Molecular Evolution, 56:407417.

MALLON, M.E., MACLEOD, A., WASTLING, J.M., SMITH, H. \& TAIT, A. 2003b. Multilocus genotyping of Cryptosporidium parvum Type 2: population genetics and sub-structuring. Infection, Genetics and Evolution, 3:207-218.

MORSE, T.D., NICHOLS, R.A.B., GRIMASON, A.M., CAMPBELL, B.M., TEMBO, K.C. \& SMITH, H.V. 2007. Incidence of cryptosporidiosis species in paediatric patients in Malawi. Epidemiology and Infection, 135:1307-1315.

MTAMBO, M.M., SEBATWALE, J.B., KAMBARAJE, D.M., MUHAIRWA, A.P., MAEDA, G.E., KUSILUKA, L.J. \& KAZWALA, R.R. 1997. Prevalence of Cryptosporidium species oocysts in cattle and wildlife in Morogoro region, Tanzania. Preventive Veterinary Medicine, 31(3-4):185-190.

MWACHARI, C., BATCHELOR, B.I., PAUL, J., WAIYAKI, P.G. \& GILKS, C.F. 2003. Chronic diarrhoea among HIV-infected adult patients in Nairobi, Kenya. Journal of Infection, 37:4853.

NACIRI, M., YVORE, P. \& LEIEUX, D. 1984. Cryptosporidiose experimentale du chevreau. Influence de la prise du colostrum. Essais de traitements, in Les maladies de la chevre, edited by $P$. Yvore \& G. Perrini. INRA Publications, Les colloques de I'INRA, no. 28, Niort, France, 9-11 October. INRA, Paris, France.

NICHOLS, G.L., CHALMERS, R.M., SOPWITH, W., REGAN, M., HUNTER, C.A., GRENFELL, P., HARRISON, F. \& LANE, C. 2006. Cryptosporidiosis: A report on the surveillance and epidemiology of Cryptosporidium infection in England and Wales. Drinking Water Directorate Contract Number DWI 70/2/201. Drinking Water Inspectorate, U.K.

NICHOLS, R.A.B. \& SMITH, H.V. 2004. Optimisation of DNA extraction and molecular detection of Cryptosporidium parvum oocysts in natural mineral water sources. Journal of Food Protection, 67:524-532.

NICHOLS R.A.B., CAMPBELL, B.M. \& SMITH, H.V. 2003. Identification of Cryptosporidium spp. oocysts in United Kingdom noncarbonated natural mineral waters and drinking waters by using a modified nested PCR-restriction fragment length polymorphism assay. Applied and Environmental Microbiology, 69:4183-4189.

NICHOLS, R.A.B., MOORE, J.E. \& SMITH, H.V. 2006. A rapid method for extracting oocyst DNA from Cryptosporidium positive human faeces for outbreak investigations. Journal of Microbiological Methods, 65:512-524.

NIZEYI, J.B., MWEBE, R., NANTEZA, A., CRANFIELD, M.R., KALEMA, G.R. \& GRACZYK, T.K. 1999. Cryptosporidium sp. and Giardia sp. infections in mountain gorillas (Gorilla gorilla beringei) of the Bwindi Impenetrable National Park, Uganda. Journal of Parasitology, 85:1084-1088.

ONGERTH, J. \& STIBBS, H. 1989. Prevalence of Cryptosporidium infection in dairy calves in western Washington. American Journal of Veterinary Research, 50:1069-1070.

PEETERS, J.E., VILLACORTA, I., VANOPDENBOSCH, E., VANDERGHEYNST, D., NACIRI, M., ARES-MAZAS, E. \& YVORE, P. 1992. Cryptosporidium parvum in calves: kinetics and immunoblot analysis of specific serum and local antibody responses (immunoglobulin A (IgA), IgG and IgM after natural and experimental infections. Infection and Immunity, 60:2309-2316.

PENG, M.M., MATOS, D., GATEI, W., DAS, P., STANTIANPAVLINIC, M., BERN, C., SULAIMAN, I.M., GLABERMAN, S., LAL, A.A. \& XIAO, L. 2001.A comparison of Cryptosporidium subgenotypes from several geographic regions. Journal of Eukaryotic Microbiology, 48:285-315.
QUILEZ, J., SANCHEZ-ACEDO, C., DEL CACHO, E., CLAVEL, A. \& CAUSAPE, A. C. 1996. Prevalence of Cryptosporidium and Giardia infections in cattle in Aragon (northeastern Spain). Veterinary Parasitology, 66(3-4):139-146.

RYAN, U.M., BATH, C., ROBERTSON, I., READ, C., ELLIOT, A., McINNES, L., TRAUB, R. \& BESIER, B. 2005. Sheep may not be an important zoonotic reservoir for Cryptosporidium and Giardia parasites. Applied and Environmental Microbiology, 71:4992-4997.

SANFORD, S.A. \& JOSEPHSON, G.K.A. 1982. Bovine cryptosporidiosis: clinical and pathological findings in forty-two scouring neonatal calves. Canadian Veterinary Journal. 23: 340-343.

SANTÍN, M., TROUT, J.M. \& FAYER, R. 2007. Prevalence and molecular characterization of Cryptosporidium and Giardia species and genotypes in sheep in Maryland. Veterinary Parasitology, 146:17-24.

SAVIOLI, L., SMITH, H.V. \& THOMPSON, R.C.A. 2006. Giardia and Cryptosporidium join the 'Neglected Diseases Initiative. Trends in Parasitology, 22:203-208.

SCOTT, C.A., SMITH, H.V., MTAMBO, M.M.A. \& GIBBS, H.A. 1995. An epidemiological study of Cryptosporidium parvum in two herds of adult beef cattle. Veterinary Parasitology, 57: 277-288.

SIMWA, J.M., CHUNGE, R.N., KINOTI, S.N., KARUMBA, P.N., WAMOLA, I., \& KABIRU, P. 1989. Cryptosporidiosis and childhood diarrhoea in a rural community in Kenya. East African Medical Journal, 66:520-525.

SMITH, H.V. 1992. Intestinal protozoa, in Medical parasitology: a practical approach, edited by P.M. Hawkey \& S.H. Gillespie. Oxford, England, UK: IRL Press, Oxford University Press.

SMITH, H.V. 2008. Cryptosporidiosis, in Manual of diagnostic tests and vaccines for terrestrial animals, $6^{\text {th }}$ ed. Office International des Epizooties, 12 rue de Prony, 75017 Paris, France.

SMITH, H.V. \& GRIMASON, A.M. 2003. Giardia and Cryptosporidium in water and Wastewater, in The handbook of water and wastewater microbiology, edited by D. Mara \& N. Horan, Oxford, England: Elsevier Science Limited.

SMITH, H.V., CAMPBELL, B.M., PATON, C.A. \& NICHOLS, R.A.B. 2002. Significance of enhanced morphological detection of Cryptosporidium sp. oocysts in water concentrates using DAPI and immunofluorescence microscopy. Applied and Environmental Microbiology, 68:5198-5201.

SMITH, H.V., CACCIÒ, S.M., TAIT, A., MCLAUCHLIN, J. \& THOMPSON, R.C.A. 2006. Tools for investigating the abiotic transmission of Cryptosporidium and Giardia infections in humans. Trends in Parasitology, 22:160-166.

SMITH, H.V. CACCIÒ, S.M., COOK, N., NICHOLS, R.A.B. \& TAIT, A. 2007. Cryptosporidium and Giardia as foodborne zoonoses. Veterinary Parasitology, 149:29-40.

SOBIEH, M., TACAL, J., WILCKE, B., LAWRENCE, W. \& ELAHRAF, A. 1987. Investigation of cryptosporidial infection in calves in San Bernadino County, California. Journal of American Medical Association, 191:816-818.

TUMWINE, J.K., KEKITIINWA, A., BAKEERA-KITAKA, S., NDEEZI, G., DOWNING, R., FENG, X., AKIYOSHI, D.E. \& TZIPORI , S. 2005. Cryptosporidiosis and microsporidiosis in Ugandan children with persistent diarrhea with and without concurrent infection with the human immunodeficiency virus. American Journal of Tropical Medicine and Hygiene, 73:921925.

VIEIRA, L.S., SILVA, M.B., TOLENTINO, A.C., LIMA, J.D. \& SILVA, A.C. 1997. Outbreak of cryptosporidiosis in dairy goats in Brazil. Veterinary Record, 140:427-428. 
WEBER, R., BRYAN, R.T., BISHOP, H.S., WAHLQUIST, S.P., SULLIVAN, J.J. \& JURANEK, D.D. 1991. Threshold of detection of Cryptosporidium oocysts in human stool specimens: evidence for low sensitivity of current diagnostic methods. Journal of Clinical Microbiology, 29:1323-1327.

WEBSTER, K.A., SMITH, H.V., GILES, M., DAWSON, L. \& ROBERTSON, L.J. 1996. Detection of Cryptosporidium parvum oocysts in faeces: comparison of conventional copro- scopical methods and the polymerase chain reaction. Veterinary Parasitology, 61:5-13.

XIAO, L. \& FENG, Y. 2008. Minireview: zoonotic cryptosporidiosis. FEMS Immunology and Medical Microbiology, 52:309-323.

ZINTL, A., NEVILLE, D., MAGUIRE, D., FANNING, S., MULCAHY, G., SMITH, H.V. \& DE WAAL, T. 2007. Prevalence of Cryptosporidium species in intensively farmed pigs in Ireland. Parasitology, 134:1575-1582. 